UDC:657.37.01

$657.37]: 334.72: 663 / 665(497.775)$

стручен труд

\title{
ПОДГОТВУВАЊЕ, ПРЕЗЕНТАЦИЈА И АНАЛИЗА НА БИЛАНСОТ НА СОСТОЈБА
}

\author{
Проф. д-р Благица Колева' ${ }^{1}$ Глорија Младенова² \\ ${ }^{1}$ Економски факултет, Универзитет „Гоце Делчев“, Штип \\ blagica.koleva@ugd.edu.mk \\ ${ }^{2}$ Економски факултет, Универзитет „Гоце Делчев“, Штип \\ glorija.083586@ugd,edu.mk
}

\begin{abstract}
Апстракт. Остварувањето на основните финансиски функции во една компанија се базираат врз податоците од нејзините финансиски извештаи. Финансиските извештаи на една компанија можат да бидат многу сложени, факт кој дополнително го истакнува значењето на финансиската анализа, преку која сложените податоци од финансиските извештаи се сведуваат на разбирливи показатели за нивните корисници - стејкхолдери.

Билансот на состојба претставува дел од задолжителниот сет на финансиски извештаи кои се изготвуваат од страна на секој деловен субјект, на крајот на секој пресметковен период. Значењето на овој финансиски извештај е големо во ефикасното менаџирање со компаниите.

Целта на овој труд е да се објасни изготвувањето и значењето на Билснсот на состојба, како дел од сетот на финансиски извештаи кои ги изготвуваат деловните субјекти, преку обработка на поимот, формите во кои се составува, содржината и обработка на финансиските показатели кои се пресметуваат со користење на билансните позиции од овој извештај.
\end{abstract}

Клучни зборови: финансиски извештаи, биланс на состојба, средства, обврски, капитал, показатели.

Abstract. Realizing the basic financial function in the company, are based on data from it's financial statements. The financial statements can be very complex, which in turn highlights the importance of financial analysis through complex data so that the financial statements have been down to understandable indicators for users of data from financial analysis.

A balance sheet is part of a set of financial statements prepared by each business entity. The significance of this report is great in the efficient management of companies.

The purpose of this thesis is to explain the preparation and significance of the Balance Sheet, as part of the set of financial statements prepared by business entities, by processing the term, the forms in which it is compiled, the content and processing of financial indicators that are calculated using the balance sheet items in this report.

Key words: financial statements, balance sheet, assets, liabilities, equity, indicators.

\section{1. Вовед}

Остварувањето на основните финансиски функции во една компанија, како што се алокацијата на средствата за одделни намени, остварување на оптимална комбинација на изворите за финансирање на одделните активности и ефикасна распределба на остварениот финансиски резултат во согласност со поставените цели на компанијата, се базираат врз податоците од нејзините финансиски извештаи. Финансиските извештаи се основа за добивање на значајни информации и претставуваат генерална слика за работењето на компанијата во одреден временски период. 
Оттука произлегува и големиот интерес на компаниите финансиските извештаи да ги приспособуваат кон своите потреби, меѓутоа, и да ја претстават колку што е можно повеќе нивната реална финансиска состојба, успешност, готовински тек и капитал. За финансиските извештаи на компанијата огромен интерес покажуваат и субјектите кои се наоѓаат надвор од неа: инвеститорите, добавувачите, кредиторите, потрошувачите, како и државата и нејзините тела. Од оваа причина општеството директно, или преку различни професионални организации, влијае врз формата и содржината на финансиските извештаи на компаниите.

Огромно значење за работењето на деловните субјекти има Билансот на состојба и неговата анализа која на корисниците на информации им овозможува многу корисни информации за работењето на компанијата. Билансот на состојба претставува систематски преглед на состојбата на средствата и изворите на тие средства на една компанија, на точно определен ден кој обично е последниот ден од годината.

Билансот на состојба на една компанија има три дела: Актива, Пасива и сопственички капитал. Вообичаено, прво се наведени главните категории на Активата, а по нив следи Пасивата. Разликата меѓу Активата и Пасивата епозната како капитал, нето капитал или нето вредност на компанијата чијашто вредноста мора да биде еднаква на Актива минус Пасива. Прецизен биланс на состојба е од суштинско значење за сопственикот на компанијата кој бара дополнително финансирање на долг или капитал или сака да го продаде бизнисот и треба да утврди колку е вреден.

Целта на овој труд е да се запознаеме со терминот Биланс на состојба, неговата форма и значење, позициите во Билансот на состојба и начинот на кој тие се вреднуваат. Исто така да утврдиме зошто е важна анализата на Билансот на состојба и финансиските показатели кои се пресметуваат од истиот.

\section{2. Поим и форма на Билансот на состојба}

Еден од основните финансиски извештаи кој се изготвува од страна на сметководствените системи на компаниите е Билансот на состојбата или, според Меѓуународните сметководствени стандарди (МCC), уште познат и како - Извештај за финансиската состојба. Билансот на состојба претставува моментална слика за финансиската состојба на одредена компанија, на одреден ден.

Билансот на состојба на една компанија има три дела: Актива, Пасива и сопственички капитал. Активата во Билансот на состојба ги прикажува средствата според видот, функцијата, односно составот. Значи од Активата може да се види со колку средства располага една организација.

Пасивата во Билансот на состојба ги прикажува изворите од кои се добиени средствата. Од неа може да се види потеклото на средствата на фирмата, дали се од сопствени или туѓи извори.

Средствата на претпријатието мора да бидат еднакви со неговите извори на средства, односно Активата мора да биде еднаква на Пасивата. Од тоа произлегува основната сметководствена равенка:

\section{АКТИВА $=$ ПАСИВА СРЕДСТВА = ОБВРСКИ + КАПИТАЛ}

Од оваа равенка, вредноста на сопствениот капитал може да се пресмета на следниот начин: 


\section{КАПИТАЛ = СРЕДСТВА - ОБВРСКИ}

Денес речиси во сите земји се применува рапортната (вертикална) форма на презентација на извештајот за финансиска состојба, во која прво се презентираат средствата на компанијата, а потоа и нивните извори. Според овој принцип, на соодветните групации на изворите треба да одговараат соодветните облици на средства. Во деловните практики на компаниите вообичаено се применуваат следните критериуми за распределба на позициите во Билансот на состојба: критериум на растечка ликвидност на средствата во Активата и опаѓачка доспеаност на обврските во Пасивата и критериум на опаѓачка ликвидност на средствата во Активата и растечка доспеаност на обврските во Пасивата.

Табела 1: Критериум на растечка ликвидност во Активата и опаѓачка доспеаност во Пасивата

\begin{tabular}{|l|l|}
\hline Актива (растечка ликвидност) & Пасива (опаѓачка доспеаност) \\
\hline Недвижности, постројки и опрема & Сопствен капитал \\
\hline Нематеријални средства & Долгорочни обврски \\
\hline Долгорочни финансиски & Краткорочни обврски \\
вложувања & \\
\hline Залихи & Тековни обврски (добавувачи и др.) \\
\hline Побарувања & \\
\hline Пари и парични еквиваленти & \\
\hline
\end{tabular}

Табела 2: Критериум на опаѓачка ликвидност во Активата и растечка доспеаност во Пасивата

\begin{tabular}{|l|l|}
\hline Актива - опаѓачка ликвидност & Пасива - растечка доспеаност \\
\hline Пари и парични еквивалент & Тековни обврски \\
\hline Побарувања & Краткорочни обврски \\
\hline Залихи & Долгорочни обврски \\
\hline Долгорочни финансиски вложувања & Сопствен капитал \\
\hline Нематеријални вложувања & \\
\hline Недвижности, постројки и опрема & \\
\hline
\end{tabular}

\section{3. Позиции во Активата на Билансот на состојба}

Средствата се ресурси кои компанијата ги контролира како резултат на минати настани и од кои се очекува прилив на идни користи во компанијата. Средствата во Билансот на состојба се поделени во две основни групи: постојани средства и тековни средства.

Постојани средства се средствата кои имаат век на употреба подолг од една година, се стекнуваат за користење во деловните операции на компанијата и не се наменети за продажба. Постојаните средства понатаму се делат на:

Нематеријални вложувања (средства) - средства кои немааат физичка форма, односно не можат да се допрат како оние кои имаат материјална форма, или пак, да се видат како средства како што се основачки вложувања, гудвил, трошоци за истражување и развој, патенти, лиценци, мостри, модели, заштитни знаци, вложувања во прибавување на нематеријални средства и др.; 
Материјални вложувања (средства) - средства од трајна природа кои се употребуваат во редовните активности на работењето (земјата, градежните објекти, машините, транспортните средства, деловниот инвентар и сл.;

Долгорочни вложувања - вложувања кои не се направени со цел да се продаваат или расходуваат во блиска иднина. Пример за долгорочни вложувања се акции, обврзници, вложување во фондови и сл.

Тековни средства. Средствата ќе бидат распределени како тековни или краткорочни, доколку се очекува да бидат потрошени во редовниот тек на оперативниот циклус на компанијата или во период до 12 месеци. Тековните средства во Билансот на состојба се презентирани според ликвидноста и опфаќаат:

- Парични средства (готовина). Паричните средства опфаќаат монети, банкноти, чекови и пари на депозит во банките со кои располага компанијата;

- Краткорочни вложувања (вложувања во должнички и сопственички хартии од вредност, кои треба да бидат реализирани во текот на една година.);

- Побарувања;

- Залихи (средства кои се чуваат за продажба во процесот на производство, или во облик на суровини за потребите на производниот процес или давањето на услугата).

- Однапред платени трошоци (АВР).

\section{4. Позиции во Пасивата на Билансот на состојба}

Пасивата, ги покажува изворите од каде потекнуваат средствата - дали средствата се сопственост на компанијата или тие се туѓи средства, т.е. не се во сопственост на компанијата. Пасивата ја сочинуваат обврските и капиталот на компанијата.

\section{Обврски}

Обврските се сегашна облигација на компанијата, која произлегува од минати настани, за чие измирување се очекува да дојде до одлив на ресурси од компанијата, кои претставуваат економски користи. Обврските на компанијата во Билансот на состојба се класифицирани како долгорочни и тековни обврски, во зависност од рокот на нивното доспевање. Секој долг кој нема да биде платен или на друг начин измирен во текот на идната година или идниот оперативен циклус, доколку циклусот е покус, се класифицира како долгорочна обврска.

Тековните (краткорочни) обврски се очекува да бидат платени во рок од една година или за време на еден оперативен циклус. Станува збор за обврски кои треба да бидат ликвидирани преку употреба на тековните средства, или преку создавање на други тековни обврски.

\section{Акционерска главнина}

Капиталот, уште познат и како акционерска главнина, го претставува сопственичкиот интерес во компанијата. Капиталот на деловниот ентитет го претставува делот од неговата вкупна вредност, кој што не е поседуван од страна на кредиторите и им припаѓ на сопствениците. Во најголем дел од сметководствените термини, капиталот претставува разлика помеѓу вредноста на имотот кој деловниот ентитет го поседува (средствата) и вредноста на она што го должи на кредиторите (обврските). Капиталот го сочинуваат: основен капитал, дополнително уплатен капитал, акумулирана (задржана добивка) и резерви. 


\section{5. Анализа на Билансот на состојба}

Анализата на финансиските извештаи на претпријатијата претставува една комплексна целина, која претставува само еден дел од целокупната анализа на работењето на претпријатието. Како таква, оваа анализа има задача да ја објасни релацијата меѓу одделните ставки од финансиските извештаи, кои комбинирани на различни начини објаснуваат различни аспекти од работењето на претпријатието: ликвидност, профитабилност, задолженост и слично.

Најпознати анализи на Билансот на состојба се Хоризонталната и Вертикалната анализа. Хоризонталната анализа е позната и под поимот Компаративна анализа со која се врши споредување на последователните Биланси на состојба за две или повеќе години, со цел согледување на промените во поединечните позиции во билансите, кои настанале во текот на анализираниот период.

Вертикалната анализа на финансиските извештаи ја открива врската, која постои помеѓу секоја поединечна ставка од финансиските извештаи и одредена специфична ставка која претставува основа и се означува со $100 \%$.

\section{6. Финансиски показатели на Билансот на состојба}

Вредностите во финансиските извештаи сами по себе не можат да бидат основа за донесување на квалификувани оценки за тековната финансиска состојба и успешност на компанијата. Токму заради тоа е потребно да се пресметаат финансиски показатели, преку кои ќе се оцени финансиската состојба на една компанија. Некои од финансиските показатели се следните:

Показатели на ликвидност (однос меѓу тековната Актива и тековната Пасива.) Коефициентот на општа ликвидност покажува можност дека од тековната Актива може да се намират тековните обврски;

Показатели на деловна активност. Показателите за користењето на средствата на компанијата, познати како показатели за обртот, се користат за проценка на користите од различните облици на средства, како што се залихите или побарувањата, или пак за проценка на користа од вкупните средства;

Показатели на солвентност. Анализата на солвентноста треба да даде одговор на прашањето дали може да се очекува дека компанијата ќе може на време да ги задоволи своите обврски на подолг рок.

\section{7. Практичен пример за „Витаминка“ АД Прилеп}

Во продолжение е претставен Билансот на состојба на „Витаминка“ АД Прилеп за 2020 година, изразен во 000 денари. Преку податоците прикажани во Билансот на состојба ќе можеме да извршиме анализа на основните финансиски показатели кои можат да се добијат преку Билансот на состојба.

Друштво: П.И. „Витаминка“ АД Прилеп

Година: 2020

Извештајот е консолидиран: Да

Во првата Табела се претставени позициите, во втората Табела се претставени податоците од претходната година (2019), а во третата Табела се податоците од тековната година (2020). Во последната Табела се прикажани индексите. 
Табела 3: Извештај за финансиската состојба (Биланс на состојба) „Витаминка“ АД Припел

\begin{tabular}{|c|c|c|c|}
\hline СРЕДСТВА & & & \\
\hline ПОСТОЈАНИ СРЕДСТВА & $1,444,292$ & $1,476,973$ & 102 \\
\hline Нематеријални средства & 3,883 & 5,220 & 134 \\
\hline Материјални средства & $1,394,099$ & $1,382,134$ & 99 \\
\hline Недвижности & 475,015 & 682,814 & 144 \\
\hline $\begin{array}{l}\text { Постројки, опрема, транспортни средства, алат, погонски и канцелариски } \\
\text { инвентар и мебел }\end{array}$ & 869,416 & 663,851 & 76 \\
\hline Биолош ки средства & & & 0 \\
\hline Останати материјални средства & 49,668 & 35,469 & 71 \\
\hline Вложувања во недвижности & 1,994 & $1,1,994$ & 100 \\
\hline Долгорочни финансиски средства & 444,316 & 87,625 & 198 \\
\hline Впожувања во подружници & 652 & 655 & 100 \\
\hline Вложувања во придружени претријатија & & & 0 \\
\hline Побарувања по дадени долгорочни заеми & & & 0 \\
\hline Вложувања во хартии од вредност & |43,664| & 86,164 & 197 \\
\hline Останати долгорочни финансиски средства & & 806 & 0 \\
\hline Долгорочни побарувања & & & 0 \\
\hline Одложено даночно средство & & & 0 \\
\hline ТЕКОВНИ СРЕДС ТВА & 717,712 & 859,919 & 120 \\
\hline Залихи & 321,732 & 463,626 & 144 \\
\hline Пообарувања од купувачите & 334,743 & 339,921 & 102 \\
\hline Останати побарувања & 37,153 & 31,940 & 86 \\
\hline Краткорочни вложувања & 40 & & 0 \\
\hline Пари и парични еквиваленти & 23,144 & 21,698 & 94 \\
\hline Платени трош оци за идните периоди и пресметани приходи (АВР) & 900 & 2,735 & 304 \\
\hline ВКУПНО СРЕДСТВА & $2,162,004$ & $2,336,892$ & 108 \\
\hline ВОНБИЛАНСНА ЕВИДЕНЦИЈА - АКТИВА & & & 0 \\
\hline ГЛАВНИНА И РЕЗЕРВИ И ОБВРСКИ & & & \\
\hline ГЛАВНИНА И РЕЗЕРВИ & $827,901 \mid$ & 855,280 & 103 \\
\hline Основна гпавнина и ревалоризациони резерви & $248,771 \mid$ & 245,639 & 99 \\
\hline Резерви & 286,857 & 313,008 & 109 \\
\hline Акумулирана добивка (загуба) & 292,273 & 296,633 & 101 \\
\hline Малцински удел & & & 0 \\
\hline ОБВРСКИ & $1,334,103$ & $1,481,612$ & 111 \\
\hline ТЕКОВНИ ОБВРСКИ & 516,226 & 449,222 & 87 \\
\hline Обврски спрема добавувачи и останати обврски & $257,971 \mid$ & 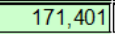 & 66 \\
\hline Обврски за краткорочни кредити и хартии од вредност & 206,742 & 190,390 & 92 \\
\hline Краткорочни резервирања & & & 0 \\
\hline Обврски кон државата & $\mid 11,308$ & 9,500 & 84 \\
\hline Останати краткорочни обврски & (40,205| & 60,880 & 151 \\
\hline Одложено плаќање на трош оци и приходи на идните периоди (ПВР) & 0 & 17,051 & 0 \\
\hline $\begin{array}{l}\text { Обврски по основ на нетековни средства (или групи за отуѓување) кои се } \\
\text { чуваат за продажба и прекинати работења }\end{array}$ & & & 0 \\
\hline ДОЛГОРОЧНИ ОБВРСКИ & $817,877 \mid$ & $1,032,390$ & 126 \\
\hline Обврски за долгорочни кредити и хартии од вредност & 817,877 & $1,032,390$ & 126 \\
\hline Обврски кон добавувачи и останати долгорочни обврски & & & 0 \\
\hline Останати долгорочни резервирања & & & 0 \\
\hline Одложени даночни обврски & & & 0 \\
\hline ГЛАВНИНА И РЕЗЕРВИ И ОБВРСКИ & $2,162,004$ & $2,336,892$ & 108 \\
\hline ВОНБИЛАНСНА ЕВИДЕНЦИЈА-ПАСИВА & & & 0 \\
\hline
\end{tabular}

Извор: https://www.mse.mk/mk/issuer/vitaminka-ad-prilep

Пресметување на показатели за „Витаминка“ АД Прилеп за 2020 година врз основа на податоците од Билансот на состојба.

1. Показател за тековна ликвидност $=$ Тековни средства / тековни обврски, т.е 859919 / $449222=1,91$

Врз основа на искуствата се смета дека коефициентот на општа ликвидност е 2,00 според некои 1,5 за кои се верува дека сите тековни обврски ќе бидат намирени на време. Согласно со резултатот можеме да заклучеме дека „Витаминка“ АД Прилеп во 2020 година се одликува со висока ликвидност. 
2. Коефициент на обрт на вкупните средства за 2020 година = Приход / Просечно користени средства т.е. 1219907 / $2249448=0,54$ Коефициентот на обрт на вкупните средства за 2020 година покажува дека приходот изнесува 54 \% во однос на користените средства.

3. Коефициент на финансиска стабилност $=($ Сопствен капитал + Долгорочни резервирања + Долгорочни обврски) / (Постојани средства + Залихи) т.е $(245639+0+1$ $032390) /(1476973+463626)=3483029 / 1940599=1.79$

Врз основа на искуствата се смета дека Друштвото има финансиска стабилност ако залихите се покриени од долгорочните извори на финансирање. Поради тоа контролната мерка за овој показател е 1,00. Бидејќи коефициентот на финансиска стабилност е поголем од 1, може да се каже дека финансиската стабилност на „Витаминка“ АД Прилеп е многу добра.

\section{Заклучоци}

Огромно значење за работењето на деловните субјекти има Билансот на состојба и неговата анализа која на корисниците на информации (компанијата и различните стејкхолдери) им овозможува многу корисни информации за работењето на компанијата. Билансот на состојба го дефинираме како систематски преглед на состојбата на средствата и изворите на тие средства на една компанија, на точно определен ден кој обично е последниот ден од годината.

Билансот на состојба претставува почетна точка во финансиската анализа. Тоа произлегува оттаму што Билансот на состојба дава претстава за висината и структурата на средствата, обврските и капиталот, коишто даваат значајни информации за кредитната способност на претпријатието.

Со анализа на Билансот на состојба, најпрвин, во најгорниот дел од Билансот на состојба се добиваат информации за средствата на претпријатието со оглед на релативната стапка на ликвидност.

Долниот дел се состои од обрските и акционерската главнина на претпријатието каде ставките се распоредени во зависност од нивниот рок на доспевање. На крајот овој финансиски извештај треба даде податоци за тоа дали во тековната година е постигната добивка или загуба.

Вредностите во финансиските извештаи или во овој случај во Билансот на состојба, сами по себе не можат да бидат основа за донесување на квалификувани оценки за тековната финансиска состојба и успешност на компанијата. Токму заради тоа е потребно да се пресметаат финансиски показатели, преку кои ќе се оцени финансиската состојба на една компанија. Финансиските показатели се релативни показатели и ги претставуваат односите меѓу одделни билансни позиции. Некои од финансиските показатели се следните:

- Показатели на ликвидност;

- Показатели на деловна активност (ефикасност на користење на средствата);

- Показатели на солвентност.

Пресметаните финансиски показатели преку кои се анализираат различните аспекти од работењето на компаниите не претставуваат цел за себе, туку само појдовна точка во понатамошната финансиска анализа. 
Во овој труд се запознавме со терминот Биланс на состојба, неговата форма и значење. Во вториот дел ги претставивме позициите во Билансот на состојба и начинот на кој тие се вреднуваат. Во третиот дел се запознавеме со анализата на Билансот на состојба и финансиските показатели кои се дел од истиот, и во четвртиот дел дадовме практичен пример за приказ и анализа на Биланс на состојба како и пресметка на основните финансиски показатели на претпријатието „Витаминка“ АД Прилеп.

\section{Користена литература:}

1. Здравкоски, 3., Здравкоски И., 2004 Сметководство - учење и практика, Економски факултет, Прилеп;

2. Колева, Б., Горгиева-Трајковска, О., „Основи на сметководство“;

3. Gilman, Stephen, „Analyzing Financial Statements“, Read books, 2007;

4. Amor, K., \& Warner, A. (2003), Uncovering Creative Accounting. London: Pearson Education Limited;

5. Bernstein, A. Leopold, 1988, „Financial Statement Analysis: Theory, application and Interpretation", Irwin;

6. Pamela P. D., Frank J. F., 2012, “Analysis of Financial Statements”, $3^{\text {rd }}$ edition;

7. Горгиева-Трајковска, О. (2010), „Финансиско известување - цели и задачи“, Годишен зборник, Универзитет „Гоце Делчев“ - Штип, Економски факултет;

8. М-р Оливера Ѓорѓиева-Трајковска (2010), Анализа на финансиските извештаи - со осврт на финансиската стабилност на корпоративниот сектор во РМ, Скопје, Докторски труд;

9. Русевски, Т., Недев, Б., Божиновска, З., Јаневски, Љ., Миновски, 3. (2004), Вовед во сметководството, Скопје;

10. Петревски, Г. (2011), „Управување со банките“ (второ издание), Скопје: Економски факултет;

11. Мицески, Т., Колева, Б., „Управување со трошоците“, Економски факултет, Универзитет „Гоце Делчев“ - Штип;

12. https://www.mse.mk/mk/issuer/vitaminka-ad-prilep

13. http://www.no.net.mk/archives/17796 